\title{
Community transmission of a virus: a global pandemic overview
}

\author{
Ravindra B. N., Lipika Das, Darshan J. C., Sayantan Ghosh*, Berlin P. Kurian, \\ Prolay Paul, Meghana A. Reddy, Satish Kumar B. P.
}

Pharmacy Practice, Sri Adichunchanagiri College of Pharmacy, B.G. Nagara, Karnataka, India

Received: 07 January 2021

Accepted: 06 February 2021

\author{
*Correspondence: \\ Dr. Sayantan Ghosh, \\ E-mail: gsayantan26@hotmail.com
}

Copyright: (c) the author(s), publisher and licensee Medip Academy. This is an open-access article distributed under the terms of the Creative Commons Attribution Non-Commercial License, which permits unrestricted non-commercial use, distribution, and reproduction in any medium, provided the original work is properly cited.

\begin{abstract}
The word 'pandemic' was originally a derivative from two Greek words "pan" referring "all" and "demos" "people". "An epidemic arising over a very diverse area, crossing the global margins, and typically affecting a huge number of people" is defined as a pandemic. Therefore pandemics are recognized by their topographical scale instead of severity of ailments. Even though the term "pandemic" has not been clearly defined, wide geographic extension, disease movement, novelty, severity, high attack rates and explosiveness, minimal population immunity, infectiousness and contagiousness can be considered as some of the key features of this term. Till today, globe has encountered several notable pandemics caused by virus such as Spanish flu, acquired immune deficiency syndrome (HIV/AIDS), smallpox, SARS, Ebola and Nipah disease whose causative organisms are H1N1, human immunodeficiency virus (HIV), Variola virus, DEN-1/DEN2/DEN3/DEN4, coronavirus, Ebola virus (Zaire/Sudan/Tai/Cote D'ivoire), and Nipah virus $(\mathrm{NiV})$ respectively. This review includes detailed data regarding various viral pandemics. Analyzing the history, clinical manifestation, pathogenesis, management and precautions of several viral pandemics which will promote and spread the awareness among the public as well as the healthcare system.
\end{abstract}

Keywords: Community transmission, Corona virus, Influenza, Pandemic, Virus

\section{INTRODUCTION}

Intermittent outbreaks of infectious diseases have had intense and lasting impact on the community throughout history. ${ }^{1}$ The word 'pandemic' was originally a derivative from two Greek words "pan" referring "all" and "demos" "people". "An epidemic arising over a very diverse area, crossing the global margins, and typically affecting a huge number of people" is defined as a pandemic. Therefore pandemics are recognized by their topographical scale instead of severity of ailments. ${ }^{3}$ Even though the term "pandemic" has not been clearly defined, wide geographic extension, disease movement, novelty, severity, high attack rates and explosiveness, minimal population immunity, infectiousness and contagiousness can be considered as some of the key features of this term. Most of all the crisis related to pandemic cause massive negative impact not only on the health and economy of various communities across the globe, but also cause significant disruptions in security of social and political area. ${ }^{4}$ It is estimated that nearly around $60 \%$ of all human infections are caused by one thousand different varieties of viruses. ${ }^{5}$ Till today, globe has encountered several notable pandemics caused by virus such as Spanish flu, acquired immune deficiency syndrome (HIV/AIDS), smallpox, SARS, Ebola and Nipah disease whose causative organisms are H1N1, human immunodeficiency virus (HIV), variola virus, DEN1/DEN2/DEN3/DEN4, coronavirus, Ebola virus (Zaire/Sudan/Tai/Cote D'ivoire), and Nipah virus (NiV) respectively (Table 1$)^{6}$.

Broadly, community transmission can be categorized into: 1) Clustered community transmission, where additional cases are from people whose tracing is impossible to known cases but are among the defined group such as cities, hovel or wide ranging events, where one can identify the growth of cases within specified 
group in exponential pattern. 2) Widespread sustained community transmission, where additional cases are from diverse, non-linked groups and self-proliferating with exponential growth of cases across these groups where most of the population of nation or territory are prone to the particular disease. ${ }^{7}$

Table 1: History of pandemic.

\begin{tabular}{|llll|}
\hline Virus and disease & Country of origin & Year of origin & Decline of outbreak \\
\hline Variola- Smallpox & Egypt & 1570 BC-1085 BC & 19779 \\
\hline H1N1 virus- Spanish flu & Spain (Mexico) & 1918 & 1919 \\
\hline HIV- AIDS & Republic of Congo, Africa & 1981 & 2006 \\
\hline Dengue virus- dengue fever & Africa and South east Asia & 1780 & 2017 \\
\hline Nipah virus- Nipah virus infection & Malaysia & 1998 & $\begin{array}{l}1999 \text { (in Malaysia), 2018 } \\
\text { (last case reported in India) }\end{array}$ \\
\hline H2N2 virus & China & 1957 & 1958 \\
\hline H3N2 virus, Hong Kong flu & China & 1968 & 1970 \\
\hline $\begin{array}{l}\text { SARS-CoV-2, coronavirus infectious } \\
\text { disease }\end{array}$ & China (Wuhan) & 2019 & Ongoing \\
\hline
\end{tabular}

Table 2: Details of various viruses.

\begin{tabular}{|c|c|c|c|c|}
\hline \multirow{2}{*}{ Virus } & \multirow{2}{*}{ Scientific name } & \multicolumn{2}{|c|}{ Taxonomy } & \multirow[b]{2}{*}{ Species } \\
\hline & & Family & Genus & \\
\hline Smallpox virus & $\begin{array}{l}\text { Variola virus } \\
(\text { VARV) })^{10}\end{array}$ & Poxviridae & Orthopoxvirus & Variola major ${ }^{11}$ \\
\hline Spanish flu & $\begin{array}{l}\text { H1N1 virus } \\
\text { (Influenza A) }\end{array}$ & Orthomyxoviridae & Alphainfluenzavirus & Influenza A virus subtype $\mathrm{H} 1 \mathrm{~N} 1$ \\
\hline HIV & HIV-1, HIV-2 & Retroviridae & Lentivirus & HIV-1, HIV-2 \\
\hline Dengue virus & $\operatorname{DENV}(1,2,3,4,5)$ & Flaviviridae & Flavivirus & Dengue virus \\
\hline Nipah virus & Nipah henipavirus & Paramyxoviridae & Henipavirus & Nipah henipavirus \\
\hline H2N2 virus & $\begin{array}{l}\text { H2N2 virus } \\
\text { (Influenza } \mathrm{A})\end{array}$ & Orthomyxoviridae & Alphainfluenzavirus & Influenza A virus subtype $\mathrm{H} 2 \mathrm{~N} 2$ \\
\hline H3N2 virus & $\begin{array}{l}\text { Influenza A virus } \\
\text { subtyoe } \mathrm{H} 3 \mathrm{~N} 2\end{array}$ & Orthomyxoviridae & Alphainfluenzavirus & Influenza A virus subtype H3N2 \\
\hline $\begin{array}{l}\text { Coronavirus } \\
\text { (SARS-CoV-2) }\end{array}$ & SARS-CoV-2 & Coronaviridae & Betacoronavirus & $\begin{array}{l}\text { Severe acute respiratory } \\
\text { syndrome- related coronavirus }\end{array}$ \\
\hline
\end{tabular}

These all are challenges, but some are even much worse than others. No matter how well we are prepared, some storms take relatively a toll. Beyond study, investigations and evolution, we need a public wellbeing attitude that comprises far more than conscripting of overall plans, as numerous countries and states have done. We need a thorough operative plan of the best way to get over 12 to 24 months of a pandemic. ${ }^{8}$

This review includes detailed data regarding various viral pandemics. Analysing the history, clinical manifestation, pathogenesis, management and precautions of several viral pandemics which will promote and spread the awareness among the public as well as the healthcare system. The information was collected through computerized search from research article and various guidelines related to pandemics using various journal sites and health care organizations. "An epidemic arising over a very diverse area, crossing the global margins, and typically affecting a huge number of people" is defined as a pandemic.

\section{SMALL POX}

Smallpox is a severe, infectious, communicable disease caused by the variola virus (minor and major), belonging to the genus Orthopoxvirus, of Poxviridae family. Virologists have ventured that it advanced from an African rodent poxvirus 10 million years ago. ${ }^{16}$ It is quite challenging to predict when exactly smallpox first infected humans, but proofs give idea that it may have first observed in the course of Neolithic age. Especially, in mummified Egyptians, Pharaoh Ramses V (d. 1157 $\mathrm{BC}$ ), provided the first reliable indication of smallpox infection. $^{17}$

\section{Clinical manifestation}

PCR analysis helps for accurate determination of lesions under certain temperature. Early symptoms includemalaise (head and body aches), fever (101-104 $\left.{ }^{\circ} \mathrm{F}\right)$, vomiting (in some cases). 
As the virus progresses following symptoms likely to develop- rash emerges as red spots turns into sores and burst rash observed on skin initiating from face progressing to arms and legs then hands and feet disseminating throughout the body within a day. On third day rash becomes bumps, fourth day bumps get loaded with fluid, fever relapses and doesn't subside until the bumps get peeled off. ${ }^{18}$

\begin{tabular}{|c|}
\hline 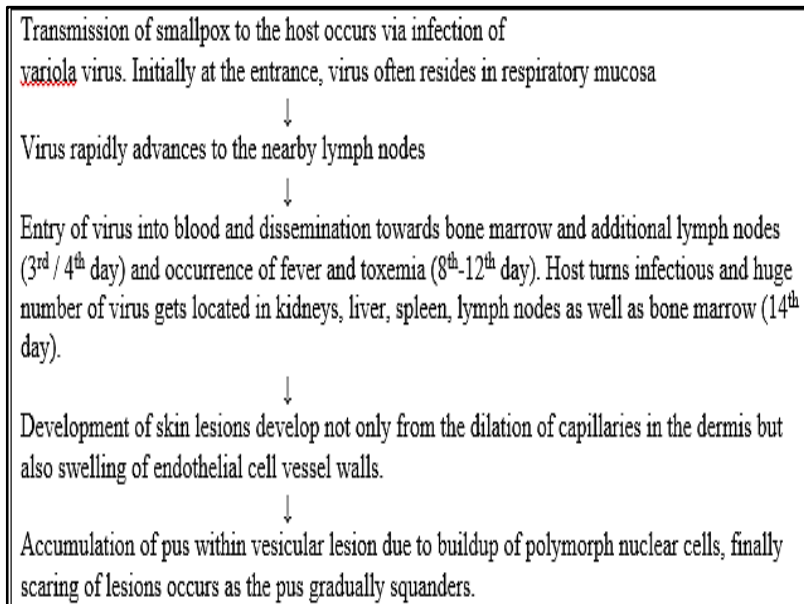 \\
\hline
\end{tabular}

Figure 1: Pathogenesis of small pox.

\section{Mode of transmission}

In variety of ways, smallpox is capable of spreading from person to person, among which transmission as a result of face to face contact for an extended period of time is the most common mode of transmission. Smallpox may also spread through direct contact with body fluids and contaminated objects. Through air or placental transmission can be considered as the rarest way by which smallpox gets transmitted.

\section{Stages of smallpox development}

Stage I: Incubation Period, usually starting from 7 to 17 days (Not contagious). Stage II: Prodromal period starting from 2 to 4 days (sometimes contagious). Stage III: Early rash in about 4 days (Most contagious). Stage IV: Pustular rash observed after 5vdays (Contagious). Stage V: Pustules and Scabs appear in about 5 days (Contagious). Stage VI: Resolving scabs within about 6 days (contagious).

\section{Treatment}

Vaccines are available to protect the people from smallpox. At present, the smallpox vaccine is not compulsory for the common people as it has been wiped out. The ACAM2000 and APSV (i.e., replicationcompetent smallpox vaccines) can defend individuals from getting sick or the disease becomes less severe if received already or within seven days of coming in contact with the virus.

\section{Antiviral drugs}

A drug called tecovirimat (TPOXX) have exhibited a prominent outcomes in preventing the progression of the virus in laboratory that is responsible for causing smallpox, which has been approved by the FDA on July 2018. It has been used in treating animals that had diseases like smallpox. Also, tecovirimat could also be used to treat adverse reactions from vaccinia vaccination under an investigational new drug (IND).

Cidofovir and brincidofovir has also shown results to stop the growth of the smallpox virus in laboratory tests. These have not been tried in people with smallpox infection, but have been tried in healthy people and in those with other viral infections. It has not been approved by FDA. It could still be used for certain unique scenarios including remote cases or during the course of an outburst under proper monitoring mechanism (like investigational new drug [IND] protocol or emergency use authorization). ${ }^{19}$

\section{SPANISH FLU}

The most austere influenza outburst of the $20^{\text {th }}$ century in terms of the numbers of deaths is the Spanish influenza pandemic of 1918-19 (Spanish flu) was among the most disastrous pandemics in history. It is caused by the virus that is transmitted through airborne respiratory secretions from person to person.

\section{Clinical manifestation}

Primarily, epithelial cells of respiratory tract are targeted. Typical influenza syndrome includes fever, cough and general aches usually lasting from 3-7 days. Some of the prominent manifestation that led to hospitalization of younger children includes laryngotracheobronchitis, pneumonia and unexplained fever. Adults are more often observed with complications of bacterial pneumonia as well as worsening chronic pulmonary disease or congestive cardiac failure. Following are some of the rarest complications- myositis, various neuralgic disorders and Reye's syndrome.

\section{ASIAN FLU}

In February 1957, after almost 40 years of H1N1 being the only influenza strain another influenza strain was spotted in the Yunnan Province of China. ${ }^{21}$ This strain was found to be milder when compared to other two influenza strains. Even though virus was transmitting during summer, community wise transmission was restricted.

\section{Clinical manifestation}

Initial symptoms include wobbly legs and a chill followed by prostration, sore throat, running nose and cough along with achy limb (adults), head (children), followed by high 
fever. In most of the condition symptoms were mild and great recovery rate have been found after a period in bed with simple antipyretic measures. Complications were seen in around $3 \%$ of the cases with the mortality rate of $0.3 \%$. Bronchitis and pneumonia makeup $50 \%$ of these, cerebro and cardiovascular disease account for remaining percentage. $^{22}$

\section{HONG KONG FLU}

Also called as 'Mao flu', arose in China in the winter of 1957 and spread rapidly worldwide starting from Hong Kong in April where about 2.5 lakh got infected, and by June over a million cases were observed in India. After a while it touched down in UK and by September in England, Wales and Scotland several cases were reported. ${ }^{23}$

\section{Clinical manifestation}

Principal findings among basic cases include malaise, fever, myalgia, cough, headache, coryza and sore throat. As per the report by the University of Singapore Health Service, some experienced atypical symptoms such as anorexia, nausea and ocular pain. ${ }^{24}$

\section{Mode of transmission of influenza viruses}

Primarily transmitted from person to person through airborne respiratory secretion in the form of large respiratory droplets $(>5 \mu \mathrm{m})$. Direct contact- touching hands (self-contamination), indirect contactcontaminated surfaces or objects (self-contamination), small particle aerosol (during aspiration or intubation. These travel only short distances usually 1 meter or less through the air.

Inhaled virus through droplets gets deposited in lower respiratory tract,
tracheobroncheal tree is the primary site of disease
Action of neuraminidase of viral envelop on n-acetylneuraminic acid
leading to liquefaction in mucus
$\downarrow$
In concert with mucociliary transport, liquefaction of mucus helps in
dissemination of virus throughout the respiratory tract
$\downarrow$
As a result of mucosal cell infection cellular destruction and
desquamation occurs in superficial mucosa

Figure 2: General pathogenesis of influenza viruses.

Table 3: Epidemiology and treatment.

\begin{tabular}{|c|c|c|c|}
\hline Viral disease & Fatality rate & Mortality rate & Vaccination \\
\hline Smallpox & $\begin{array}{l}\text { Before vaccine- } 7.6 \%(1 \\
\text { in } 13 \text { death })^{13} \\
\text { After vaccine- }<1 \%\end{array}$ & $\begin{array}{l}\text { Variola minor- } 1 \% \\
\text { Variola major- } 30 \%\end{array}$ & $\begin{array}{l}\text { Smallpox vaccine by Edward Jenner } \\
\text { in } 1796-\text { Vaccinia (Ankara strain, City } \\
\text { Board of Health Strain), double } \\
\text { stranded DNA virus }{ }^{14}\end{array}$ \\
\hline Spanish flu & $>2.5 \%$ & 50- 100 million worldwide & No vaccine \\
\hline AIDS & $100 \%$ & $60 \%$ & No vaccine \\
\hline Dengue fever & & $\begin{array}{l}<1 \% \text { (early detection), } 2-5 \% \\
\text { (severe dengue when treated), } \\
20 \% \text { (when untreated })^{15}\end{array}$ & Dengvaxia (CYD-TDV) in 2015 \\
\hline $\begin{array}{l}\text { Nipah virus } \\
\text { infection }\end{array}$ & $\begin{array}{l}>70 \% \text { (In India and } \\
\text { Bangladesh), 40-75\% } \\
\text { (worldwide) }\end{array}$ & $>75 \%$ & No vaccine \\
\hline Asian Flu & $0.67 \%$ & 1.1 million & $\begin{array}{l}\text { Influenza Virus vaccine, monovalent } \\
\text { type A (Asian strain } 5 \mathrm{ml} \text { ) }\end{array}$ \\
\hline Hong Kong flu & $0.5 \%$ & $16.9 \%$ & $\begin{array}{l}\text { NYMC X-203, NYMC X-203A, } \\
\text { NYMC X-213, IDCDC- RG55C }\end{array}$ \\
\hline $\begin{array}{l}\text { Coronavirus } \\
\text { infectious disease }\end{array}$ & $\begin{array}{l}1.52 \% \text { (India), } 0.1-25 \% \text { in } \\
\text { countries worldwide }\end{array}$ & $3.4 \%$ & $\begin{array}{l}\text { BNT162, mRNA-1273, Ad5-nCoV, } \\
\text { AZD1222, CoronaVac, Covaxin, JNJ- } \\
\text { 78436735, NVX-CoV2373, Sputnik V }\end{array}$ \\
\hline
\end{tabular}

\section{ACQUIRED IMMUNO DEFICIENCY SYNDROME (AIDS)}

HIV1 pandemic is a compound mixture of various epidemics within and among different countries as well as regions of world, effecting thousands of people leading to public health crisis. On estimation, around 38.6 million people survived with HIV1 throughout the world whereas about 25 million have already died. In 2005, highest number of HIV1 cases (4.1 million) have been found and 2.8 million expired of AIDS. Based on their genetic structure, HIV1 viruses are grouped into 3 groups: M, N and $\mathrm{O}^{25}$ 


\section{Clinical manifestations and opportunistic infections}

Fever (96\%), lymphadenopathy (74\%), pharyngitis and rash $(70 \%)$, myalgia/arthralgia (54\%), diarrhea and headache $(32 \%)$, weight loss $(13 \%)$, neurologic symptoms (12\%), fungal infections; (oral candidiasis), Coccidioidomycosis, Cryptococcosis. Viral infections: encephalopathy, herpes simplex virus, histoplasmosis, Kaposi's sarcoma. Bacterial infections: tuberculosis, pneumonia, Mycobacterium avium complex, Progressive multifocal leukoencephalopathy. Parasitic infection: toxoplasmosis.

\section{CDC stages}

Stage 1: Acute HIV Infection. Stage 2: Asymptomatic HIV. Stage 3: Early symptomatic HIV. Stage 4: Late symptomatic HIV: A) Constitutional disease. B) Neurological disease. C) Secondary infection. C1- AIDS Defining. C2- Other infections. D) Secondary cancers. E) Other conditions

\section{Pathogenesis}

\section{Mode of transmission}

HIV is transmitted primarily via following routes: infected blood, semen, vaginal fluids, breast milk.

Selective tropism for $\mathrm{CD} 4$ molecule receptor

$$
\downarrow
$$

Internalization

$\downarrow$

Uncoating and viral DNA formation

$\downarrow$

Viral integration and replication

$\downarrow$

Latent period and immune attack

$\downarrow$

CD4+ T Cell destruction and viral dissemination

Figure 3: Pathogenesis of AIDS.

The majority of HIV transmission takes place through male to female transmission and the basis of viral spread on this transmission route is not known. Another common route of transmission is mother to child transmission. ${ }^{26}$

\section{Treatment}

No cures exist for AIDS, but strict adherence to antiretroviral regimens can radically slow down disease's advancement by keeping the viral load under control.
Effective management of HIV infection is possible using combination various available drugs. This method of treatment is collectively called as antiretroviral therapy.

\section{FDA approved HIV drugs}

Reverse transcriptase inhibitors- group of drugs which has a potential to bind and inhibit an enzyme called reverse transcriptase to interrupt the multiplication of HIV. There are two types of inhibitors: 1) Non-nucleoside reverse transcriptase inhibitors (NNRTI): First generation NNRTIs include Nevirapine, Delaviridine and Efavirenz which have poor resistance profile as well as low genetic barrier. Hence, development of new generations that is second generation NNRTIs were done including Etravirine and Rilpivirine. 2) Nucleoside reverse transcriptase inhibitors (NRTI): These drugs can be considered as 'backbone' of antiretroviral therapy (ART) regimens since past two decades. They selectively target HIV-1 reverse transcriptase enzyme and causes inhibition of viral RNA replication. These drugs donot go through phase I hepatic metabolism, making them devoid of drugdrug interactions. Examples include: Zidovudine, Stavudine and Festinavir (structural analogue of thymidine). ${ }^{27}$

Protease inhibitors- For the accurate assembly and production of HIV, regulation of HIV protease is extremely crucial. They effectively block the functioning of protease enzyme in both acutely as well as chronically HIV infected CD4 cells. Examples include lopinavir/ ritonavir, indinavir, neflinavir and amprenavir. ${ }^{28}$

\section{HIV Protease Inhibition}

$\downarrow$ Results in

Liberation of immature and noninfectious viral particles.

Figure 4: Mechanism of action of protease inhibitors.

Fusion inhibitors- A classic examples for this class of drugs are: Enfuvirtide which works by blocking HIV from getting into the CD4 cells of infected patients. Fusion inhibitors also work by obstructing the fusion of HIV particles with CD4 cells. ${ }^{29}$

Chemokine receptors 5 antagonist- They block chemokine receptor (CCR5) which are situated on CD4 cells. Maraviroc is an example of a CCR5 antagonist used in HIV treatment. ${ }^{30}$

Integrase strand transfer inhibitors- By acting integrase enzyme they avoid the integration of viral DNA into host genome of CD4 cells. Blocking of integrase enzyme prevents HIV from replicating. Examples: elvitegravir, raltegravir and dolutegravir. ${ }^{3}$ 
Table 4: FDA approved four influenza antiviral drugs suggested by CDC for use against influenza viruses.

\begin{tabular}{|c|c|c|c|c|c|}
\hline \multicolumn{2}{|l|}{ Drug } & \multirow{2}{*}{ Class } & \multicolumn{2}{|c|}{ Dose and route of administration } & \multirow{2}{*}{ Adverse effects } \\
\hline Generic name & Brand name & & Paediatric & Adult & \\
\hline Peramivir & Rapivab & $\begin{array}{l}\text { Antiviral, } \\
\text { Neuraminidase } \\
\text { inhibitors }\end{array}$ & $\begin{array}{l}12 \mathrm{mg} / \mathrm{kg} \text { i.v. as a } \\
\text { single dose }(2-12 \\
\text { years }), 600 \mathrm{mg} \text { i.v. as } \\
\text { a single dose ( } \geq 13 \\
\text { years) }\end{array}$ & $\begin{array}{l}600 \mathrm{mg} \text { i.v. as a single } \\
\text { dose }\end{array}$ & $\begin{array}{l}\text { Neutrophils }<1 \times 10^{9} / 1 \text {, } \\
\text { increased serum } \\
\text { glucose }(>160 \mathrm{mg} / \mathrm{dl}) \text {, } \\
\text { AST and ALT } \\
\text { increased, constipation, } \\
\text { insomnia, hypertension }\end{array}$ \\
\hline Zanamivir & Relenza & $\begin{array}{l}\text { Antiviral, } \\
\text { Neuraminidase } \\
\text { inhibitors }\end{array}$ & $\begin{array}{l}10 \text { mg inhaled q } 12 \\
\text { hours for } 5 \text { days, start } \\
\text { within } 2 \text { days of } \\
\text { symptom onset }\end{array}$ & $\begin{array}{l}10 \mathrm{mg} \text { inhaled q day } \\
\text { for } 10 \text { days, start } \\
\text { within } 2 \text { days of } \\
\text { symptom onset. } \\
\text { Community outbreaks: } \\
\text { begin within } 5 \text { days of } \\
\text { outbreak, may } \\
\text { administer for up to } 28 \\
\text { days. }\end{array}$ & $\begin{array}{l}\text { Headache, throat/tonsil } \\
\text { pain, cough, viral } \\
\text { infection }\end{array}$ \\
\hline Oseltamivir & Tamiflu & $\begin{array}{l}\text { Antiviral, } \\
\text { Neuraminidase } \\
\text { inhibitors }\end{array}$ & $\begin{array}{l}75 \mathrm{mg} \text { PO q day for } \\
\text { atleast } 10 \text { days }(\geq 13 \\
\text { years), <15 kg: } 30 \\
\text { mg PO q day for } \\
\text { atleast } 10 \text { days ( } 1-12 \\
\text { years) }\end{array}$ & $\begin{array}{l}75 \mathrm{mg} \text { PO q } 12 \text { hours } \\
\text { for } 5 \text { days }\end{array}$ & $\begin{array}{l}\text { Abdominal pain, } \\
\text { conjunctivitis, } \\
\text { epistaxis, insomnia, ear } \\
\text { disorder, virtigo }\end{array}$ \\
\hline $\begin{array}{l}\text { Baloxavir } \\
\text { Marboxil }\end{array}$ & Xofluza & $\begin{array}{l}\text { Antiviral, } \\
\text { Endonucleus } \\
\text { inhibitors }\end{array}$ & $\begin{array}{l}40 \mathrm{mg} \text { PO as a single } \\
\text { dose }(40-80 \mathrm{~kg}, \geq 12 \\
\text { years }),<12 \text { years: } \\
\text { safety as efficacy not } \\
\text { established }\end{array}$ & $\begin{array}{l}40 \mathrm{mg} P O \text { as a single } \\
\text { dose }(40-80 \mathrm{~kg}), \geq 80 \\
\mathrm{~kg}: 80 \mathrm{mg} \mathrm{PO} \text { as a } \\
\text { single dose }\end{array}$ & $\begin{array}{l}\text { Diarrhea, bronchitis, } \\
\text { nasopharyngitis }\end{array}$ \\
\hline
\end{tabular}

Recent recommendations by WHO for antiretroviral therapy $(A R T)$

First-line ART: Adults- Consists of two NRTIs and one NNRTI. Tenofovir disoproxil fumerate (TDF) + Lamivudine (3TC) or Emtricitabile (FTC) + Efavirenz (EFV).

Alternatively, 1) Zidovudine + 3TC + EFV. 2) AZT + $3 \mathrm{TC}+$ Nevirapine or. 3) TDF + 3TC + NVP.

Pediatrics: For patients $<3$ years, initially given with protease inhibitors such as lopinavir/ritonavir, even under the exposure of NNRTI. For patients $>3$ years, EFV is the best choice of NNRTI whereas NVP has been recognized as secondary option.

Second-line ART: Used when first line ART treatment miss the mark. Adults- Primarily two NRTIs and Retonavir- boosted PI, AZT and 3TC can be considered as a recommended option.

Pediatrics: $<3$ years, first line ART is recommended to continue even when it fails. No change in treatment is recommended. Alternative to this some of the key steps should be taken in order to enhance adherence to the ART regimen. It consists of one NNRTI and two NRTIs.
Recommended option is AZT $+3 \mathrm{TC}$ in case ABC or TDF +3 TC fails.

Third-line ART: Includes integrase inhibitors together with second generation NNRTIs as well as PIs. ${ }^{32}$

\section{CORONAVIRUS INFECTIOUS DISEASE}

Wuhan, China witnessed the first ever outbreak of novel coronavirus infection in December 2019. Even after the launch of an emergency response during the initial stage of outbreak, the infection spontaneously disseminated to metropolitan areas of China as well as worldwide. It is caused by newly discovered coronavirus strain (SARSCoV-2). These group of RNA viruses are morphologically resemble a crown like structure that primarily causes the infections either in nose, sinus or in upper throat. ${ }^{33}$

\section{Clinical manifestation}

Based on severity, authors of Chinese CDC report divided the clinical manifestations of the disease as mild, severe and critical. Most common symptoms include cough, breathlessness, dry mouth, and sore throat. 
Mild disease includes non-pneumonia and mild pneumonia which occurred in around $81 \%$ of cases.

Severe conditions include respiratory frequency less than 30 per minutes, dyspnea, blood oxygen saturation greater than $93 \%, \mathrm{PaO}_{2} / \mathrm{FiO}_{2}$ ratio or $\mathrm{P} / \mathrm{F}$ and the percentage of oxygen supplied greater than 300 , and /or lung infiltrate less than $50 \%$ within 1-2 days; around $14 \%$ of cases are found with above data.

Critical disease include approximately $5 \%$ of cases that are found with critical diseases like septic shock, respiratory failure, and/ or multiple organ dysfunction or failure. $^{34}$

\section{Mode of transmission}

Initial cases of corona virus infectious disease were associated with direct exposure to Huanan Seafood Wholesale Market. The main mechanism was assumed as animal to human transmission which was not proved in subsequent cases as the viral spread was not seen from animals to humans. Hence, it was clinched that the virus is transmitted from human to human. The most repeated source of COVID-19 transmission is considered to be symptomatic people. As there are chances of transmission prior to symptoms, and hence individual who stay asymptomatic could spread virus, the best way to combat this pandemic is remaining isolated. As seen in other respiratory pathogens, including rhinovirus and flu, it was assumed that spreading of virus occur from coughing and sneezing through respiratory droplets of particle size greater than $5-10 \mu \mathrm{m}$ in diameter. $80 \%$ of COVID-19 transmissions are associated with pre and asymptomatic individuals. The transmission is initially restricted to family members, healthcare professionals and other closed contacts around 6 feet, 1.8 meters. Details regarding duration of contamination on objects and surfaces are as follows: Plastic: 2-3 days, Stainless steel: 2-3 days, Cardboard: 1 day, Copper: 4 hours. ${ }^{35}$

\section{Pathogenesis}

The mechanism by which SARS-CoV-2 produces symptoms seems to be complex. +ssRNA of around length $30 \mathrm{~kb}$ embedded in a genomic structure of virus. It comprised of $5^{\prime}$-cap and $3^{\prime}$-poly-A tail. Beginning from viral RNA the production of poly protein $1 \mathrm{a} / 1 \mathrm{ab}$ in the host is recognized. Organization of replicationtranscription complex (RCT) in double membrane vesicles and through the production of sub genomic RNA sequences is the modes via which the process of transcription occurs. Transcription regulatory sequences which are situated within the open reading frames (ORF), work as templates for sub genomic mRNAs. Generally, in a typical genome of coronavirus at least 6 ORFs may be present among which ORF $1 \mathrm{a}$ and $1 \mathrm{~b}$ directs the synthesis of pp1a and pp1ab polypeptides which are processed by proteases, chymotrypsin-like protease and main protease. Among the structural components of viruses, two subunits S1 and S2 are embedded within glycoproteins. Homo trimers of $\mathrm{s}$ proteins makeup the spikes on the surface of virus directing the link to host receptors. Receptor binding domain (RBD) represents a binding site for binding site for human angiotensin converting enzyme 2 receptor (ACE 2 receptor). Polybasic site allows the functional processing of ACE 2 by an enzyme called protease which allows the acquaintance of fusion sequences and thereby virus and cell membranes get fused. ${ }^{36}$

\section{Treatment}

Currently, there is no specific antiviral treatment or vaccine found for COVID-19. Symptomatic treatment is encouraged and oxygen therapy is considered as first step against respiratory impairment. In case of respiratory failure refractory to oxygen therapy non-invasive (NIV) and invasive mechanical ventilation. For complicated forms of disease intensive care is mandatory.

$\mathrm{O}_{2}$ fast challenge- In a patient with oxygen saturation $<93-94 \%$ (If COPD, 88-90\%) or dyspnea, administration of oxygen by a $40 \%$ venturi mask must be undertaken. Reassessment is done after 5-10 min to determine any improvement of clinical features. Treatment is continued in case of improvement whereas noninvasive treatment is chosen if the condition is worsening. ${ }^{37}$

High flow nasal oxygen (HFNO)- Generally indicated when it is hard to maintain $\mathrm{SpO}_{2}>92 \%$ and adjustment is done according to the clinical response by supplying 3040 litres/minute and $\mathrm{FiO}_{2}$ around 50-60\%. If no improvement is seen after an hour when given with $>50$ litres/minute and $\mathrm{FiO}_{2}>70 \%$, then switch to NIV. HFNO can also be considered to break CPAP and also for fibreoptic tracheal intubation in critically ill patients. HFNO is contraindicated in hypercapnic patients.

Non-invasive ventilation and continuous positive airway pressure- Begins with $8-10 \mathrm{~cm} \mathrm{H}_{2} \mathrm{O}$ and $\mathrm{FiO}_{2} 60 \%$. NIV starts with PEEP $5 \mathrm{~cm} \mathrm{H}_{2} \mathrm{O}$ checking the tolerance of patient and bring to $8-10 \mathrm{~cm} \mathrm{H}_{2} \mathrm{O}, \mathrm{FiO}_{2} 60 \%$, PS $8-10 \mathrm{~cm}$ $\mathrm{H}_{2} \mathrm{O}$.

It is not recommended to make any changes in first day, at least after 4-6 hours detach for maximum 1 hour only stabilized. Small quantities of fluid are allowed to intake during night. ${ }^{38}$

Antiviral agents- Even though no antiretroviral treatments have been approved, several approaches have been put forward like lopinavir/ritonavir, 400/100 mg orally every 12 hours. Preclinical studies recommended that, an inhibitor of RNA polymerase with in vitro activities against multiple RNA viruses called remdesivir could be effective for prophylaxis as well as therapy of coronavirus infection. ${ }^{39}$ 
Several anti-flu medications like oseltamivir have been recommended for COVID-19 treatment. Favipiravir, another anti-flu drug which proved to be efficacious against SARS-CoV-2 invitro. In a retrospective investigation a broad spectrum antiviral called arbidol was shown to be a good agent which not only can improve discharging rate but also decrease mortality rate of Covid-19 patients. $^{40}$

Immunomodulatory drugs- Initially chloroquine, $500 \mathrm{mg}$, every 12 hours and hydroxychloroquine (HCQ), $200 \mathrm{mg}$, every 12 hours were recommended as immunomodulatory therapy. These drugs especially HCQ was considerably associated with reduction of viral load which was boosted by macrolide antibiotic, azithromycin. ${ }^{41}$

Serotherapy- From the blood of healed individuals antibodies are taken and are studied for therapeutic option.

Inflammation inhibitors- A humanized IgG1 monoclonal antibody, directed against IL-6 receptors called as tocilizumab is investigated by an Italian foundation. Other interleukin receptor antagonist/antibody namely sarilumab and anakinra used to treat auto inflammatory disorders such as adult-onset stills disease, systemic onset juvenile idiopathic arthritis and familial Mediterranean fever. $^{42}$

\section{PRECAUTIONS}

Most of the viral pandemics mentioned above spread through prolonged face to face contact via droplets expelled from the nose and mouth of a patient, generally by coughing. A disease like smallpox is also transmitted through contact with materials from smallpox scabs. Following are some of the predominant measures that are mandatory to follow in order to get through these pandemics. $^{43}$

Usage of person protective equipment (PPE): It is necessary that all the staffs of healthcare team as well as visitors or any other person coming in close contact with the patient to follow standard, contact as well as airborne precautions regardless of vaccination status.

Criteria for PPE: Disposable gown and gloves. NIOSH certified N95 filtering disposable respirator. Eye protections such as face shields are mandatory in case of medical procedures which may lead to splashing or spraying of patients body fluids.

Before exiting patient's room it is required to remove all PPE, except for N95 respirator. After removal of gloves, the staff members must wash his/her hands either with soap or alcohol based hand sanitizer. ${ }^{44}$

Disinfected and sterilized environmental surfaces: The nature and magnitude of surface contamination will recite the level of disinfection either as low or intermediate, needed to make the surface safe to handle or use. Fumigation isn't a relying method of disinfecting rooms, facilities or vehicles containing variola virus. ${ }^{45}$

Disposable medical apparatuses and patient care devices: 'Category A' wastes are imparted with certain guidelines called waste management guidelines which are of prime importance in maintaining overall hygiene of entire healthcare team as well as public.

High efficiency particulate air (HEPA) filters: Usage of vacuum cleaner installed with a high efficiency particulate air filter for cleaning carpeted floors or upholstered furniture.

Disposal of all waste contaminated with viruses is considered to be category A infectious substance which is regulated as hazardous materials under the US Department of transportation containing set of regulations which require special packaging hazardous materials prior to transport. ${ }^{46}$

\section{CONCLUSION}

Rigorous understanding of various pandemics or outbreaks and consequences of their community spread across the globe till date along with their etiology as well as primary root of origin is crucial. To determine the impact of various communicable diseases on nation's economic status, to explore the role of healthcare expenditures in bringing down various pandemics, to notice any fluctuations in poverty rates and population density due to different pandemics, to understand the importance of individual's behavioural change by strengthening oneself psychologically for combating against various possible outbreaks that may occur in most unpredictable manner and most importantly helping Government of our nation to take commendable, stringent and most accurate decisions for the purpose of all round development of a country including key areas such as economy and health status.

Funding: No funding sources Conflict of interest: None declared Ethical approval: Not required

\section{REFERENCES}

1. Huremović D. Brief history of pandemics (pandemics throughout history). In: Psychiatry of Pandemics. Springer: Cham; 2019:7-35.

2. Yamamoto T. Pandemic control measures. Japan Med Assoc J. 2013;56(1):51-4.

3. WHO (World Health Organization). 2010. "What Is a Pandemic?" WHO; February 24. Available from: http://www.who.int/csr/disease/swineflu/frequently_ asked_questions/pandemic/en/. Accessed on 5 September 2020. 
4. Qiu W, Rutherford S, Mao A, Chu C. The pandemic and its impacts. Health cult Soc. 2017;9:1-1.

5. Barker J, Stevens D, Bloomfield SF. Spread and prevention of some common viral infections in community facilities and domestic homes. J Appl Microbiol. 2001;91(1):7-21.

6. Madhav N, Oppenheim B, Gallivan M, Mulembakani P, Rubin E, Wolfe N. Pandemics: risks, impacts, and mitigation. Disease control priorities. 3rd edn. Vol. 9: Improving health and reducing poverty. World Bank Group; 2017.

7. Cabore JW, Karamagi HC, Kipruto H, Asamani JA, Droti B, Seydi AB, et al. The potential effects of widespread community transmission of SARS-CoV2 infection in the World Health Organization African Region: a predictive model. BMJ Glob Health. 2020;5(5):e002647.

8. Osterholm MT. Preparing for the next pandemic. $\mathrm{N}$ Engl J Med. 2005;352(18):1839-42.

9. Riedel S. Edward Jenner and the history of smallpox and vaccination. Baylor Univ Med Center Proceed. Taylor and Francis. 2005;18(1):21-25.

10. Babkin IV, Babkina IN. The origin of the variola virus. Viruses. 2015;7(3):1100-12.

11. Hussain AN. Smallpox: Background, Etiology, Epidemiology. Medscape. 2015.

12. Breman JG, Henderson DA. Diagnosis and management of smallpox. $\mathrm{N}$ Engl $\mathrm{J}$ Med. 2002;346(17):1300-8.

13. Ochmann S, Roser M. Smallpox. Our World in Data, 2018 Jun 28. Available from: https://ourworldindata.org/smallpox. Accessed on 6 September 2020.

14. Belongia EA, Naleway AL. Smallpox vaccine: the good, the bad, and the ugly. Clin Med Res. 2003;1(2):87-92.

15. Irawati AD, Salim HM. Dengue vaccine development at the dengue virus serotypes. Int Islam Med J. 2019;1(1):9-15.

16. Hussain AN. Smallpox virion. Courtesy of US Centers for Disease Control and Prevention.

17. Alibek K. Smallpox: a disease and a weapon. Int $\mathbf{J}$ Infect Dis. 2004;8:3-8.

18. Moore ZS, Seward JF, Lane JM. Smallpox. Lancet. 2006;367(9508):425-35.

19. Centers for Disease Control and Prevention. Smallpox disease overview. Smallpox Fact Sheet. Available at: http://www.bt.cdc.gov/agent/smallpox/overview/dis ease-facts.asp.2004. Accessed on 5 September 2020.

20. Britannica IE. Encyclopædia Britannica. Encyclopaedia Britannica, Incorporated; 1957.

21. Pyle GF. The diffusion of influenza: patterns and paradigms. New Jersey: Rowman and Littlefield; 1985:218.

22. Finer DI, Scott K. Influenza epidemic. Br Med J. 1957;2(5054):1180.

23. Honigsbaum M. A history of the great influenza pandemics: death, panic and hysteria, 1830-1920. IB Tauris; 2013.
24. Kadri ZN. An outbreak of "Hong Kong flu" in Singapore. Singapore Med J. 1970;11:30-2.

25. Joint United Nations Programme on HIV/AIDS (UNAIDS). 2006 report on the global AIDS epidemic: a UNAIDS 10th anniversary special edition. World Health Organization; 2006.

26. Hübner W, McNerney GP, Chen P, Dale BM, Gordon RE, Chuang FY, et al. Quantitative 3D video microscopy of HIV transfer across $\mathrm{T}$ cell virological synapses. Science. 2009;323(5922):1743-7.

27. de Béthune MP. Non-nucleoside reverse transcriptase inhibitors (NNRTIs), their discovery, development, and use in the treatment of HIV-1 infection: a review of the last 20 years (1989-2009). Antiviral Res. 2010;85(1):75-90.

28. Hughes PJ, Cretton-Scott E, Teague A, Wensel TM. Protease inhibitors for patients with HIV-1 infection: a comparative overview. Pharm Therap. 2011;36(6):332.

29. Greenberg ML, Cammack N. Resistance to enfuvirtide, the first HIV fusion inhibitor. J Antimicrob Chemother. 2004;54(2):333-40.

30. Rao PK. CCR5 inhibitors: Emerging promising HIV therapeutic strategy. Indian J Sex Transmit Dis AIDS. 2009;30(1):1.

31. Pandey KK, Grandgenett DP. HIV-1 integrase strand transfer inhibitors: novel insights into their mechanism of action. Retrovirol Res Treat. 2008;2:11.

32. World Health Organization. Guideline on when to start antiretroviral therapy and on pre-exposure prophylaxis for HIV. World Health Organization; 2015:78.

33. Li Q, Guan X, Wu P, Wang X, Zhou L, Tong Y, et al. Early transmission dynamics in Wuhan, China, of novel coronavirus- infected pneumonia. N Engl J Med 2020;382:1199-207.

34. Wu Z, McGoogan JM. Characteristics of and important lessons from the coronavirus disease 2019 (COVID-19) outbreak in China: summary of a report of 72314 cases from the Chinese Center for Disease Control and Prevention. JAMA. 2020;323(13):1239-42.

35. Guo ZD, Wang ZY, Zhang SF, Li X, Li L, Li C, et al. Aerosol and surface distribution of severe acute respiratory syndrome coronavirus 2 in hospital wards, Wuhan, China, 2020. Emerg Infect Dis. 2020;26(7):10-3201.

36. Song W, Gui M, Wang X, Xiang Y. Cryo-EM structure of the SARS coronavirus spike glycoprotein in complex with its host cell receptor ACE2. PLoS Pathogens. 2018;14(8):e1007236.

37. Gattinoni L, Coppola S, Cressoni M, Busana M, Rossi S, Chiumello D. Covid-19 does not lead to a "typical" acute respiratory distress syndrome. Am J Respir Crit Care Med. 2020;201(10):1299-300.

38. Hui DS, Chow BK, Lo T, Tsang OT, Ko FW, Ng SS, et al. Exhaled air dispersion during high-flow 
nasal cannula therapy versus CPAP via different masks. Eur Respir J. 2019;53(4):1802339.

39. Gordon CJ, Tchesnokov EP, Feng JY, Porter DP, Götte M. The antiviral compound remdesivir potently inhibits RNA-dependent RNA polymerase from Middle East respiratory syndrome coronavirus. J Biol Chem. 2020;295(15):4773-9.

40. Wang Z, Yang B, Li Q, Wen L, Zhang R. Clinical features of 69 cases with coronavirus disease 2019 in Wuhan, China. Clin Infect Dis. 2020;71(15):76977 .

41. Kollias A, Kyriakoulis KG, Dimakakos E, Poulakou G, Stergiou GS, Syrigos K. Thromboembolic risk and anticoagulant therapy in COVID-19 patients: emerging evidence and call for action. $\mathrm{Br} \mathrm{J}$ Haematol. 2020;189(5):846-7.

42. Della-Torre E, Campochiaro C, Cavalli G, De Luca G, Napolitano A, La Marca S, et al. Interleukin-6 blockade with sarilumab in severe COVID-19 pneumonia with systemic hyperinflammation: an open-label cohort study. Ann Rheumat Dis. 2020;79(10):1277-85.

43. Rutala WA, Weber DJ. Guideline for disinfection and sterilization in healthcare facilities. Centre for Disease Control and Prevention. 2008.

44. Sehulster L, Chinn RY. Healthcare Infection Control Practices Advisory Committee (HICPAC). Guidelines for environmental infection control in health-care facilities. Recommendations of CDC and the HICPAC. MMWR Recomm Rep. 2003;52(10):1-42.

45. Aitken C, Jeffries DJ. Nosocomial spread of viral disease. Clinical Microbiology Reviews. 2001;14(3):528-46.

46. Carden JL Jr. Hazardous waste management. United States: Springer-Verlag New York Inc; 1985.

Cite this article as: Ravindra BN, Das L, Darshan JC, Ghosh S, Kurian BP, Paul P, et al. Community transmission of a virus: a global pandemic overview. Int J Community Med Public Health 2021;8:1518-27. 